\title{
Historical and Current Legislations of Taman Negara National Park
}

\section{Peninsular Malaysia}

\author{
Pakhriazad., H.Z , Mohd. Hasmadi, I. \& Aida, H.M.K \\ Faculty of Forestry \\ Universiti Putra Malaysia \\ Serdang 43400, Selangor. Malaysia
}

Tel: 60-3-8946-7225Ｅ-mail: asato40@hotmail.com

\author{
Kamaruzaman Jusoff (Corresponding author) \\ Yale University \\ School of Forestry \& Environmental Studies \\ 205 Prospect St, New Haven, CT 06511-2104, USA
}

Tel: 203-676-7761Ｅ-mail: jusoff.kamaruzaman@yale.edu

This research is funded by Universiti Putra Malaysia (sponsoring information)

\begin{abstract}
The study was conducted to discuss the historical and current legislation pertaining to the establishment and administration of the Taman Negara National Park, Peninsular Malaysia. Established in 1938 and 1939 as King George V National Park, the park was named Taman Negara National Park after independent in 1957. Estimated to be 130 million years old and with an area of 4,343 sq kilometers, the highest mountain in the peninsular, Gunung Tahan $(2,187$ meter) is allocated in the area. Taman Negara National Park is a combination of three protected areas in three states, Taman Negara Pahang National Park, Taman Negara Kelantan National Park and Taman Negara Terengganu National Park. Currently all the three states has its own legislation, namely Taman Negara Enactment (Pahang) No.2, 1939 [En.2 of 1938], Taman Negara Enactment (Kelantan) No.14, 1938 [En.14 of 1938 ] and Taman Negara Enactment (Terengganu) No.6, 1939 [En.6 of 1358]. In Malaysia, some laws are federal legislation. Others are state enactments. Not all legislation enacted will apply to the whole Peninsular, the state of Sabah and Sarawak. To provide for the establishment and control of National Parks and for matters connected herewith, the Federal National Parks Act (Act 226) was introduced in 1980. This federal act shall not apply to the three states. Since this is the constitutional position, constraints especially on uniformity of laws either to promote or enforced, particularly in respect matters stated and List 1 Federal List (Ninth Schedule of Article 74, 77 Legislative Lists), List II - State List (Article 95B (1) (a) and List III Concurrent List (Article 95B (1) (b) often exists. Thus, there are some matters which the National Parks fall under the legislative authority of both the Federal and State Governments. However, forestry and land fall under the jurisdiction and legislative authority of the state in accordance with the Concurrent List of the Ninth Schedule. The areas of jurisdiction of Federal and State Governments as defined in the Constitution lead to non-uniform implementation of rules and regulations between states. The objective of this paper is to review the laws and legislation pertaining to the management of the National Park in Peninsular Malaysia. Specifically the constraints arises between the federal and states jurisdiction toward the management of land and conservation of the protected area.
\end{abstract}

Keywords: Taman Negara National Park, Protected areas, Historical, Legislations, Gazettement

\section{Introduction}

The Federation of Malaysia is divided in two geographical areas, Peninsular Malaysia (PM) in the west and the State of Sabah and Sarawak in the east ${ }^{(1)}$. The states of Federation shall be Johore, Kedah, Kelantan, Malacca, Negeri Sembilan, Pahang, Penang, Perak, Perlis, Sabah, Sarawak, Selangor and Terengganu (Section 2, Federal Constitution). In PM, 
protected areas include national and state parks, protection forest of the Permanent Reserves Forest (PRF), wildlife reserves and sanctuaries ${ }^{(2)}$. The history of managing conservation areas in the PM started in 1894 when the first law namely the Straits Settlement Ordinance No.3 of 1894 was passed (Elagupillay 1993). The first protected area, the Chior Games Reserve was created in 1903 with the passing of the Wild Animal and Birds (Perak) Enactment in 1902. While the protection of forest remains under the state lists, the protection of wildlife and national parks fall under the federal lists.

The other Federated Malay States passed a series of their own legislation. The most significant being the passing of three similar enactments namely the Taman Negara enactments of Kelantan, Terengganu and Pahang between 1938 and 1939 which led to the creation of the tri-state Taman Negara National Parks (TNNP).Theodore Hubback of the British Colonial office researched the potential of establishing a national park for extensive protection of the biological resources for scientific, recreational, and educational interests (Steven, 1968).In 1938, His Highness the Sultan of Pahang, Kelantan and Terengganu have declared their desire jointly to commemorate the silver jubilee of the accession to the Throne of the Majesty King George V of Britain by the dedication of certain land situate in each of the said States which shall constitute together as National Park [Gazette (Kelantan Section) Notification No. 2, $3^{\text {rd }}$ January, 1952]. During the period, the gazettment of the land is in perpetuity for the propagation, protection and preservation of the indigenous flora and fauna of Malaya. The preservation of objects and places of aesthetic, historical or scientific interest shall herewith relevant to any contiguous lands dedicated, set aside or reserved for similar purposes within the tri-states of Kelantan, Terengganu and Pahang to constitutes the TNNP. The King George V National Park Taman Negara Enactment (Pahang) No.2, 1939 [En.2 of 1938], Taman Negara Enactment (Kelantan) No.14, 1938 [En.14 of 1938] and Taman Negara Enactment (Terengganu) No.6, 1939 [En.6 of 1358] was gazetted as an Enactment to provide for the dedication of the lands in the respective states as part of the TNNP. The National Park has been gazetted as the State Park together to constitute the Taman Negara as agreed by His Highness the Sultans of the three States and His Excellency the High Commissioner as constituted by the Enactments of the respective states. The State Park shall vest from time to time jointly in such persons as shall be fulfilling the duties and exercising the powers of the Sultans of the respective state and of the Yang di Pertuan Agong (the Supreme Ruler of Malaysia) respectively who shall hold and administer the said lands as Trustees.

\section{Methods and materials}

\subsection{Study area}

The present study was conducted in the Taman Negara National Parks related areas in the State of Pahang (2, 477 sq. $\mathrm{km}$ or $57 \%$ ), Kelantan (1, $043 \mathrm{sq} . \mathrm{km}$ or $24 \%$ ) and Terengganu (853 sq. km or 19\%), Peninsular Malaysia (PM) in February and Mei 2008 (Fig.1) The State of Pahang which is located in the East Coast state in PM is the largest state with 2,071,585 ha of forested area (Pakhriazad, 2004) and having the largest portion of the TNNP. The PM is located between latitudes 1'20' to 6'45' north of the Equator and longitudes 99'40' to 104'20' east, with the total land area of 132 million ha.

\subsection{Data collection}

Three methods were employed to collect the data, the review of the official documents, interviews and survey. The reviewed documents included the federal and state government official reports and gazettes on the policies, administration and legislation of TNNP and the conservation of state land. The interviews were carried out with the relevant state authority, Federal and State Forestry Department, other related agencies such as Wildlife Department, Natural Resources and Environment Department, state subsidiaries and representatives. The interview focused on investigating the state authority policies with regard to the administration on the areas. Field study and area observation was also conducted during two expeditions at TNNP in order to understand the actual situation of the relevant agencies responsibilities on managing the areas.

\section{Results and discussion}

\subsection{Establishment of legislation in Pahang, Kelantan and Trengganu}

As stated in the First Schedules to the Taman Negara (Pahang) Enactment 1939 [En.2 of 1938], The King George V National Park (Pahang) was gazetted (Pahang Section) as TNNP in 1939 which covers an area of 2,477 sq km or 57\% of the total area. Majority of the land area is mountainous with peaks such as Gunung Teku, Gunung Tangga Dua Belas and Gunung Tahan. The Tahan River, which originates from Gunung Tahan is the main river that create the drainage system in Taman Negara Pahang National Park. The vegetation of Taman Negara Pahang National Park is made up of dipterocarp and montane forest and rich in fauna diversity like large mammals and endemic wildlife. The administrative centre at Kuala Tahan is the main entrance to the Taman Negara Pahang National Park. The second entrance is located at Sungai Relau, Merapoh with several enforcement posts at park boundary of Kuala Yu, Kuala Terenggan, Kuala Kenyam.

The description of boundries of the part of Taman Negara National Park in Pahang includes all the area of land 
amounting to 2, $477 \mathrm{sq} \mathrm{km}$ more or less in the Daerah of Lebir in the District of Ulu Terengganu bounded as follows; commencing from Gunung Rabong (5040) and proceeding in a direct line, bearing approximately $109^{\circ} 15^{\prime}$, to a point about one mile due south of Kampong Pakoh, thence in a direct line, bearing approximately $77^{0} 15^{\prime}$, to Kuala Manis on the true right bank of the River Ibu Lebir, above Kuala Ampul; thence by the true right bank of the River Manis for one mile from Kuala Manis, thence north-easterly to Kuala Alor, a tributary of the River Pertang, thence by the true right bank of the River Alor following the ancient Pagan track to near the source of the River Alor and to the Terengganu-Terengganu boundary; thence south easterly following the Pahang-Pahang boundary; and southerly and westerly following the Pahang-Terengganu boundary to Gunung Tahan (7186'); thence north-westerly following the Terengganu-Pahang boundary to a joint where it meets the Daerah Lebir boundary (Ulu Sungai Ngeram); thence in a direct line to the point of commencement (Ahmad-Nordin, 1951).

As for the state of Kelantan, in the exercise of the powers conferred by section 10 of the King George V National Park (Kelantan) Enactment 1938, His Excellency the High Commissioner and His Highnesses the Sultan of Kelantan, as Trustees under the said Enactment of the State Park, hereby cited the Rules of the King George V National Park (Kelantan) Enactment No. 14 of 1938 [En.14 of 1938] and King George V National Park (Kelantan) Rules 1951 for the purpose of the administration of the State Park. Whereas it is expedient to make provision for the dedication and administration accordingly of so much of the land as is situated in the State of Kelantan, it is hereby enacted by His Highness the Sultan in Council that the National Park can be defined s the State Park together with the other areas in Pahang and Terengganu as may be constituted by Enactments in those States together to constitutes Taman Negara (Section 2, Enactment No. 14 of 1938). The State Park shall vest from time to time jointly in such persons as shall be fulfilling the duties and exercising the powers of the Sultan of Kelantan and of the Yang di Pertuan Agong (The Supereme Ruler of the Federation) respectively who shall hold and administer the said land as Trustees. His Highness the Sultan in Council on the application of the Trustees may by notification amend the schedule in respect of the boundaries of the State Park as therein set out and described provided that such amendment is in the opinion of the trustees necessary or desirable in order to secure greater ease of description or demarcation of the said boundaries or greater ease in the administration of the State Park and provided that such amendment does not result in any substantial decrease in the total area of the State Park (Section 4, Enactment No. 14 of 1938). Taman Negara Kelantan National Park covers an area of 1,043 sq. $\mathrm{km}$ or $24 \%$ of the total area of TNNP. Located on the southwest of Kelantan, Taman Negara Kelantan National Park forms the northern portion of TNNP. The terrain is made up of mountain and valley with several peaks such as Gunung Rabong and the Gunung Tahan Range. Taman Negara Kelantan National Park is drained by four major river systems; Sungai Relai on the west, Sungai Aring and Sungai Lebir in the middle and Sungai Badong on the east. The administrative centre for Taman Negara Kelantan National Park is located at Kuala Koh

The description of boundaries of the part of Taman Negara National Park which lies in Kelantan includes all the area of land amounting to 198, 300 acres more or less in the Daerah of Lebir in the District of Ulu Kelantan bounded and commencing from Gunung Rabong (5040) and proceeding in a direct line, bearing approximately $109^{\circ} 15^{\prime}$, to a point about one mile due south of Kampong Pakoh, thence in a direct line, bearing approximately $77^{0} 15^{\prime}$, to Kuala Manis on the true right bank of the River Ibu Lebir, above Kuala Ampul; thence by the true right bank of the River Manis for one mile from Kuala Manis, thence north-easterly to Kuala Alor, a tributary of the River Pertang, thence by the true right bank of the River Alor following the ancient Pangan track to near the source of the Kelantan-Terengganu boundary and southerly and westerly following the Pahang-Kelantan boundary to Gunung Tahan (7186'); thence north-westerly following the Kelantan-Pahang boundary to a point where it meets the Daerah Lebir boundary (Ulu Sungai Ngeram); thence in a direct line to the point of commencement (Ahmad-Nordin, 1951).As provisions to the like effect exist in the law of the State of Pahang or of the State of Terengganu respectively if any person is known reasonably suspected to have done in any part of the TNNP lying within the State of Pahang or within the State of Terengganu respectively any act which if it had done in the State of Kelantan would have constituted and offence against the Enactment or against any rule made there under and such person is found within or immediately on his arrest has been done brought into the State of Kelantan such person may be dealt within all respects as if such act had in fact been done within the State of Kelantan. In addition to the provisions is to the like effect exist in the law of the State of Pahang or of the State of Terengganu respectively any person who has done within the State of Kelantan any act which constitutes any offence against this Enactment or against any Rule made there under and who is found within or immediately on his arrest has been taken into the State of Pahang or the State of Terengganu respectively may within the State be dealt within all respects as if such persons had in fact been done within such state (Section 13, Enactment No. 14 of 1938).

Meanwhile for the case of Trengganu state, the King George V National Park (Terengganu) Enactment [En.6 of 1358 ] was gazetted (Terengganu Section) by Notification on No.2, $3^{\text {rd }}$ January 1952 . In exercise of the powers conferred by section 10 of the King George V National Park (Terengganu) Enactment 1938, His Excellency the High Commissioner and the Highness the Sultan of Terengganu as trustee under the said Enactment of the State Park, hereby make the rules and Enactment namely the King George V National Park (Terengganu) Rules 1851 and the King George V National Park (Terengganu) Enactment, 1938. Taman Negara Terengganu National Park with an area of 853 sq. km is the 
smallest component of TNNP. The area consists of water bodies, limestone outcrops and mountainous are covered by natural forests. Some of the highest peaks in this part of the park include Gunung Gagau, Gunung Mandi Angin, Gunung Sembilu and Gunung Gemuk. This park is drained by Sungai Chinchin, Sungai Chendana, Sungai Mentong, Sungai Pertang and Sungai Terenggan. A portion of Tasik Kenyir lakes juts into the park. The main entrance to the park is located in Tanjong Mentong.

The description of boundaries of the part of TNNP which lies in Terengganu includes all the area of land amounting to 198, 300 acres more or less in the Daerah of Lebir in the District of Ulu Terengganu bounded as follows; commencing from Gunung Rabong (5040) and proceeding in a direct line, bearing approximately $109^{\circ} 15^{\prime}$, to a point about one mile due south of Kampong Pakoh, thence in a direct line, bearing approximately $77^{\circ} 15^{\prime}$, to Kuala Manis on the true right bank of the River Ibu Lebir, above Kuala Ampul; hence by the true right bank of the River Manis for one mile from Kuala Manis, thence north-easterly to Kuala Alor, a tributary of the River Pertang, thence by the true right bank of the River Alor following the ancient Pagan track to near the source of the River Alor and to the Terengganu-Terengganu boundary; thence south easterly following the Terengganu-Terengganu boundary; and southerly and westerly following the Terengganu-Pahang boundary to Gunung Tahan (7186'); thence north-westerly following the Terengganu-Pahang boundary to a joint where it meets the Daerah Lebir boundary (Ulu Sungai Ngeram); thence in a direct line to the point of commencement (Ahmad-Nordin, Z., 1951).

\subsection{Federal-State and the Legislation of the Taman Negara National Parks}

Federal-State relationships with emphasis on natural resources management at TNNP and protected area has been described in many reports (Shafruddin, 1987).Nevertheless, the subject continue to generate much interest as the relationship is dynamic and continually evolving particularly in response to changing social, political, economic and environmental, is the emergence of new institutional arrangements especially at the level of the state in the establishment and management of TNNP in the PM. Issues on lack of coordination among the Federal and the State governments, conflicting targets and mandates on the managing of the areas are often exists (Cheryl,2005). The integration and consolidation of the laws and administration structures are further tied up to the country's constitution and the federal and states relationship (Musa, N., 2000). In Malaysia, the Federal Constitution provides for a system of levels of government (federal and state) which are separate, yet interdependent. It specifies jurally relationship should be expressed and the boundaries of federal and state jurisdictions. It is however silent about the real political operations within which federalism operate (Shafruddin 1988). Some laws are federal legislation. The others are state enactments. Not all legislation enacted will apply to the whole Peninsular, the state of Sabah and Sarawak. Since this is the constitutional position, the question of how uniformity of laws may be promote or enforced, particularly in respect matters which fall under state jurisdiction need to be properly addressed. This is specified by the Federal Constitution, under the List 1 Federal List (Ninth Schedule of Article 74, 77 Legislative Lists), List II - State List (Article 95B (1) (a) and List III - Concurrent List (Article 95B (1) (b). Subject matter of federal and state laws stated that without prejudice to any power to make laws conferred on it by any other Article, the Legislature of a State may make laws with respect to any of the matters enumerated in the State Lists, the Second List set out in the Ninth Schedule or the Concurrent List (Article 74 (2), Federal Constitution). Thus, there are some matters, for example the National Parks fall under the legislative authority of both the Federal and State Governments in accordance with the Concurrent List of the Ninth Schedule. However, there are some matters which fall under the legislative authority of the state for example forest and agriculture. National Forestry Act 1984 (Amend. 1993) is a federal legislature for the purpose of promoting uniformity of laws of two or more states under Article 76 (1)(b) of Federal Constitution - however its applicable to the state upon its adoption and hence become a state law. The National Land Code 1965 is a federal legislature for ensuring uniformity of law and policy under Article 76(4) of the Federal Constitution.

The areas of jurisdiction of Federal and State Governments as defined in the constitution lead to a uniform implementation between states. The legal mechanism under the respective state and federal laws serves to complement each other and its legal framework envisages that the state and federal government integrating in achieving the common goal. To provide for the establishment and control of National Parks and for matters connected herewith, the Federal National Parks Act 1980 (Act 226) $^{(3)}$ and National Parks (Amendment) Act 1983 was later introduced by the federal government. However, the Act shall not apply to the states of Sabah and Sarawak in the East Malaysia and the State Parks of Kelantan, Pahang and Terengganu which together constitute the Taman Negara as described in the Schedule to the Taman Negara Enactment (Kelantan) No.14, 1938 [En.14 of 1938], Taman Negara Enactment (Pahang) No.2, 1939 [En.2 of 1938], and Taman Negara Enactment (Terengganu) No.6, 1939 [En.6 of 1358] (Section 1(2) National Parks Act 1980). Differ from the British occidental laws of the National Parks establishment, the current objective of the establishment of National Parks is for the preservation and protection of wild life, plant life and objects of geological, archaeological, historical and ethnological and other scientific and scenic interest and through their conservation and utilization to promote the education, health, aesthetic values and recreation of the people. The other legislation pertaining to this act is the Protection of Wildlife Act 1976 which is repealed to pro-Merdeka law which consolidated all State Enactments/Ordinances on protection of wild life and birds especially in a protected area such as Taman Negara 
National Parks. The earliest of wildlife reserve established in the Peninsular Malaysia (PM) is the Chior Wildlife Reserve, Perak, which was gazetted in 1902. It is the first wildlife reserve in the country. The same are was gazetted as a forest reserve in 1914 and therefore overlapping status as wildlife reserve and forest reserve. The original area was 4, 330 ha but was decreased gradually as some areas were degazetted to agriculture and other uses. The remaining are stands at 689 ha. Bukit Kutu Wildlife Reserve, Selangor was established in 1922. The area is located $24 \mathrm{~km}$ south of Kuala Kubu Bahru. The area is steep, reaching up to 1, 053 meters at its highest level. Part of its 1, 493 ha overlaps with forest reserve. The largest wildlife reserve in Peninsular Malaysia is allocated is Krau Wildlife Reserve, located at Gunong Benom in the district of Temerloh, Pahang. Established in 1923, the area is irrigated by Sungai Krau, Sungai Lompat and Sungai Teris. The altitude in the reserve ranges from 43 meters in Kuala Lompat to 2, 107 meters at the peak of Gunung Benom. Sungkai Wildlife Reserve area of 2,468 ha which is located in the Southern part of Perak was established in 1928. The 4.5 ha Batu Gajah Wildlife Reserve, Perak was established in 1952 under Perak State Gazette Notification 766. Another area is the 1,335 ha of Pahang Tua Wildlife Reserve which was established in 1954 under Gazette No. 402 to protect doves. It is located between the Pekan-Kuantan which covers a few mangroves islands along Sungai Pahang Tua. The 4,330 ha of Sungai Dusun Wildlife Reserve, Selangor was established in 1964 under the Selangor State Government Gazette No. 359. The reserve is located approximately $120 \mathrm{~km}$ north of Kuala Lumpur. Generally, the reserve is made up of lowland dipterocarp and peat swamp forest with the highest elevation at 253 meters above sea level. Sungai Dusun and Sungai Tengi form the boundary of the reserve in the north and south respectively. A canal on the west of the reserve connects Sungai Tengi to Sungai Bernam. Bukit Fraser Wildlife Reserve, Pahang covers the ecotourism area that borders the Selangor-Pahang boundary. At an elevation of 1, 219 meters, it adjourns another reserve in Selangor. This reserve overlaps the local authority area and parts of it overlaps with forest reserve.

In Malaysia, some laws are federal legislation. The others are state enactments. Not all legislation enacted will apply to the whole Peninsular, the state of Sabah and Sarawak. To provide for the establishment and control of National Parks and for matters connected herewith, the Federal National Parks Act (Act 226) was introduced in 1980 This federal act shall not apply to the three states. Since this is the constitutional position, constraints especially on uniformity of laws either to promote or enforced, particularly in respect matters stated and List 1 Federal List (Ninth Schedule of Article 74, 77 Legislative Lists), List II - State List (Article 95B (1) (a) and List III - Concurrent List (Article 95B (1) (b) often exists. Thus, there are some matters which the National Parks fall under the legislative authority of both the Federal and State Governments. However, forestry and land fall under the jurisdiction and legislative authority of the state in accordance with the Concurrent List of the Ninth Schedule. The areas of jurisdiction of Federal and State Governments as defined in the Constitution lead to non-uniform implementation of rules and regulations between states. The management of the National Parks faced several problems such as unclear border demarcation, absence of buffer zones and uncoordinated development at the adjacent areas (Law, 2000). The decisions related to gazetting, de-gazetting of protected areas, appear to be related primarily to economic factors, which are a powerful influence in land use policy, particularly at the state level. The policy statement of The National Policy on Biological Diversity is to conserve Malaysia's biological diversity and to ensure that its components are utilized in a sustainable manner for the continued progress and socio-economic development of the nation (NPCBD, 1994). The other multiple-values may include social (Gumai and Tan 1992, Lim et al.1999), economic (Burkhill 1935, Awang 1995), ecological (Salleh and Manokaran 1994, Lim and Chin 1994) and spiritual (Hood 1994, Zakiah 1994).

\section{Conclusion}

In this paper, the historical and current legislation pertaining to the establishment and administration of the Taman Negara National Park in Peninsular Malaysia were assessed. The King George V National Park was then established in 1938/1939. The park is made-up of a tri-state area within the states of Pahang, Trengganu, and Kelantan. It was established to commemorate King George V of England. In 1960, following the independence of Malaya, the name of the park was changed to Taman Negara National Park. The administration of Taman Negara National Park is within the jurisdiction of the Trustees who are the Sultans of the states of Pahang, Kelantan and Trengganu, and the Yang Pertuan Agong. Taman Negara National Park is a combination of three protected areas in three states, Taman Negara Pahang National Park, Taman Negara Kelantan National Park and Taman Negara Terengganu National Park. Currently all the three states has its own legislation, namely Taman Negara Enactment (Pahang) No.2, 1939 [En.2 of 1938], Taman Negara Enactment (Kelantan) No.14, 1938 [En.14 of 1938] and Taman Negara Enactment (Terengganu) No.6, 1939 [En.6 of 1358]. Not all legislation enacted will apply to the whole Peninsular, the state of Sabah and Sarawak. To provide for the establishment and control of National Parks and for matters connected herewith, the Federal National Parks Act (Act 226) was introduced in 1980. This federal act shall not apply to the three states. Since this is the constitutional position, constraints especially on uniformity of laws either to promote or enforced, particularly in respect matters stated and List 1 Federal List (Ninth Schedule of Article 74, 77 Legislative Lists), List II - State List (Article 95B (1) (a) and List III - Concurrent List (Article 95B (1) (b) often exists. Thus, there are some matters which the National Parks fall under the legislative authority of both the Federal and State Governments. However, forestry and land fall under the jurisdiction and legislative authority of the state in accordance with the Concurrent List of the Ninth 
Schedule. The areas of jurisdiction of Federal and State Governments as defined in the Constitution lead to non-uniform implementation of rules and regulations between states.

\section{Footnotes}

(1) Since December 1989, "West Malaysia" shall be construed as reference to Peninsular Malaysia (Interpretation Acts, 1967).

${ }^{(2)}$ Federal protected areas in Peninsular Malaysia refer to national parks, wildlife reserves, wildlife sanctuaries, marine parks, and other protected forest reserves that were gazette by federal legislation since the early $1900_{s}$. However, the establishment of federal protected areas was limited by states right over land ownership. (DWNP et al.1996).

(3) Date of Gazette on 28 February 1980 and Enacted as Act 226on 29 February 1980.

(4) Date of Amendments of Act A571 on 28 November 1983 (Dlm.I.N. (S) 5/2 Jld. II dated 3 December, 1983).

\section{References}

Ahmad-Nordin, Z. (1951). In:Taman Negara National Park Enactment No.6 of 1939 Government of Terengganu. Clerk of Councils, Government of Terengganu.

Awang, N.G. (1995). Economic Valuation of Genetic Resources. Paper presented at the Workshop on Prospects and Problems of Biodiversity Prospecting, UKM, Malaysia.

Burkill, I. (1935). A Dictionary of Economic Products of the Malay Peninsula. Vol.192.

Chery,R.K. (2005). National Ecotourism Plan: Assessing Implementation of the Guidelines for Marine Parks. Centre for Coastal \& Marine Environment, Maritime Institute of Malaysia, p.17.

DWNP, EPU, and DANCED. (1996). Capacity building and strengthening of protected areas system in Malaysia: A master plan. Department of Wildlife and National Parks, Kuala Lumpur, Peninsular Malaysia.

Federal Constitution. (1957)

Gumai, M. and S.S. Tan. (1992). Some Aspects of Social Forestry in Sarawak. Paper presented at the $11^{\text {th }}$ Malaysian For. Conf., Kota Kinabalu, Sabah.

Hood, S. (1993). Rimba Sebagai Persekitaran. Paper presented at the Conference of Eco-tourism in Malaysia: Prospect and Potential Impact. Kuala Lumpur.

Law, H.D. (2000). In: The Workshop on the Management and Conservation of Protected Areas; Administrative and Legislative Issues, Kuala Lumpur. 4-5 July 2000.

Lim, M.T. and T.Y. Chin. (1994). A Practical Approach to Conservation of Genetic Diversity in Malaysia: Genetic Resource Area. Paper presented at the IUFRO Symposium on Measuring an Monitoring Biodiversity in Tropical and Temperate Forests, Chiang Mai, Thailand.

Musa, N. (2000). In: The Workshop on the Management and Conservation of Protected Areas; Administrative and Legislative Issues, Kuala Lumpur. 4-5 July 2000.

National Technical Committee on Biological Diversity (NTCBD) (1994). The National Policy on Biological Diversity. Draft, 20 August 1994.

Shafruddin, B.H., (1988). Malaysian centre-state relations by design and process. In. B.H. Shafruddin and Iftikhar A.M.Z Fadzli (eds.) Between Centre and State: Federalism in Perspective. Kuala Lumpur, Institute of Strategic and International Studies.

Salleh, M.N. and N. Manokaran. (1994). Monitoring of Forest Biodiversity: policy and research issues. Paper presented at the IUFRO Symposium on Measuring and Monitoring Biodiversity in Tropical and Temperate Forests, Chiang Mai, Thailand. 